\title{
Preferences in Senior High School Tracks of the Grade 10 Students
}

\author{
Jerald C. Moneva ${ }^{1 \#}$ \& Marsha H. Malbas ${ }^{2}$ \\ ${ }^{12}$ Graduate School Professors, University of the Visayas-Main Camps, Cebu City, \\ Philippines.
}

\#corresponding author.

Type of Work: Peer-Reviewed

DOl: http://dx.doi.org/10.21013/jems.v15.n5.p2

\section{How to cite this paper:}

Moneva, J.C., Malbas, M.H. (2019). Preferences in Senior High School Tracks of the Grade 10 Students. IRA International Journal of Education and Multidisciplinary Studies (ISSN 2455-2526), 15(5), 167-174.doi: http://dx.doi.org/10.21013/jems.v15.n5.p2

(C) Institute of Research Advances.

This work is licensed under a Creative Commons Attribution-Non Commercial 4.0 International License subject to a proper citation to the publication source of the work.

Disclaimer: The scholarly papers as reviewed and published by the Institute of Research Advances (IRA) are the views and opinions of their respective authors and are not the views or opinions of the IRA. The IRA disclaims of any harm or loss caused due to the published content to any party.

Institute of Research Advances is an institutional publisher member of Publishers International Linking Association Inc. (PILA-CrossRef), USA. The institute is an institutional signatory to the Budapest Open Access Initiative, Hungary advocating the open-access of scientific and scholarly knowledge. The Institute is a registered content provider under Open Access Initiative Protocol for Metadata Harvesting (OAI-PMH).

The journal is indexed \& included in WorldCat Discovery Service (USA), CrossRef Metadata Search (USA), WorldCat (USA), OCLC (USA), Open J-Gate (India), EZB (Germany) Scilit (Switzerland), Airiti (China), Bielefeld Academic Search Engine (BASE) of Bielefeld University, Germany, PKP Index of Simon Fraser University, Canada. 


\begin{abstract}
There are many influences that affect the preferences of grade 10 students in choosing a track to proceed to senior high school. Likewise, this study aims to identify influence of preference of a Senior High School track that is commonly encountered by the Grade 10 students in terms of Gender, Socio-Economic Status, Average academic grades, nature of parent's occupation; and, strand and the level of influence of the respondent to be associated with preferences in choosing a track in senior high school in terms of family influence-decision; peer influence; financial condition; and employability. The research tool was a survey questionnaire. The questionnaire is composed of respondent's profile and 10 statements to be rated. The factors fairly influence preferences of the senior high school. In terms of gender, male students consider their socio-economic status and their parent's occupation as factors in choosing their track in Senior High School while female students consider their peers as a factor in choosing a track in Senior High School.
\end{abstract}

Keyword: Academic Track, Career Choice, Decision-making, Influences, Senior High School Preferences

\title{
Introduction
}

Uncertainty is an unavoidable as well as career decision entailing unexpected outcomes[1]. Choosing a career is crucial especially among students in the secondary or in middle school. In making decisions in career selection, one has to undergo an intricate process and forcefully open-minded person to choose his speciality, practice and location of the educational institution [2]. Result expectancies, learning experiences, sex, personal interests and contacts influence the choice of career among students which leads to confusion, doubts and undecidedness of the students[3]. Undecidedness about choice of major course to take is a common condition on tertiary levels today [4]. To mention, money and average grade quota restrictions as potential obstruction of decision-making and major changers of desired career among students because it prohibited students to enrol from entering the productive field. undecided students are affected by the differences in institutional practices, policies, and attitudes[5].Students should not be in a permanent status of undecideness[6][7]. Misfit of choosing a career may result in unemployment and underemployment [8]. Professional life and future achievement is a result of the appropriate choice of career among students [9]. Students become confused, for instance, negative perceptions in certain specialities of a preferred career[10].Advising is helping students to realize with their own ideas, feeling, and effort to understand and make meaningful concepts in the choice of their career [11]. Teachers are more influential compared to career counsellors [12]. Unfortunately, internet society has most probably replaced the influence of the family in this contemporary society [13].

In relation to this, this input information relays the crucial role of preferences of a senior high school track among grade 10 students. In this study, the process includes the gathering of data which uses the descriptive-analytical method using the survey questionnaire from the desired number of respondents of grade 10 students. The process pertains in organizing the collected data, analyzing and giving an interpretation of data. Lastly, recommendations shall help the students in choosing their desired track in senior high school when influential factors on the preferences of the grade 10 students are determined.

\section{Statement of Purpose}

This study aims to assess some selected factors associated with of preferences of senior high school track that are commonly adopted by the Grade 10 students of a secondary national high school of the school year 2017-1018. Specifically, it attempted to determine the profile of Grade 10 students in terms of gender, socio-economic status, parent's occupation consideration, strand-like Accountancy and Business Management(ABM), General Academic Strand (GAS), and Humanities and Social Sciences (HUMSS). Then, the researcher determines the level of influence to the Grade 10 students toward track preferences in Senior High School in terms of family influence and decisions, peer influence, financial condition; and employability. Finally, the association between the profile and level of influence of the Grade 10 students towards track preference for the Senior High School is also determined. 
Hypothesis

$\mathrm{H}_{0}$ : There is no significant association between the factors and the roles of preference of a Senior High School track of the grade 10 students.

$\mathrm{H}_{1}$ : There is a significant association between the factors and the roles of preference of a Senior High School track of the grade 10 students.

\section{Related Review of Literature}

A lot of factors must be considered in choosing a course. Gender is a crucial factor among students in their choice of a course. Gender distinguishes female students to be inclined to artistic related careers while male students select scientific-related careers[14]. Gender differences exist in selection of speciality medical courses [15][16]. On the contrary, in choosing journalism traditional sex-role stereotypes as careers become irrelevant[17]. It does not make any variations of influence of family members, peers, teachers and guidance counsellors in the choice of career [12]. Gender differences ascertain preferred specialities [18]. Also, similarity of career choice may be depicted in cases like mother and daughter close relationship [13] while in developing and undeveloped countries, career decision making for college is influenced by parents particularly the father [16].

Aside from gender, before entering college, socio-economic and related factors include lifestyle among some medical students [2][16]; personal factors, socio-economic factors and socializers determine career choice, the prestige of the course, indication of well-paying job and bright future prospects, influence of demand of job [20]; personality [8], personal interest and previous positive clerical experience [21]); job security, interest, less competition, less hours of practice, less investment and influenced by friends[22]. Remuneration is a paramount factor among accounting students to be in the profession[23], but financial reward does not determine the choice of a career [21]; socio academics, cultural factors and university including entrance examination [24]. Whereas, professionals preparation between government and academic positions are different [25]. Though, type of occupations which require similar investment do but differ in income do not necessarily influence the choice of a student [26].

Academic and academic-related factors include, ability and intellect determines career success among students [8] interest [20] particular learning style [14]; curricular - extracurricular and one's experiences, income, career choices, status, work-life equilibrium, labor content, and hours of working, [16]; adequate motivational, cognitive, and metacognitive skills which meet job or family responsibilities shall prepare students for science courses [27], and grade point average, advice from other people, and orientation session attendance [21]. Among medical students, the chosen career is relevant to the successful product of the medical-educational institution, the program offered and the characteristic of medical student [28].

Decision-making, negative thinking and career difficulties indicate undecidedness of a student [7]. In order for students to make a better decision, one can consider interest and intellectual ability [8]; interest in the subject, relationship with peers, members of the family and teachers, and by assessment and research in the internet and other sources before making the decision [29]. Many students need career counselling for choosing correct career path as clinical researcher or clinical practitioner [30]. The approach to supporting student willingness is a potential influence [6].

In terms of personal qualities, low self-confidence in the classroom implicates the behaviour to be less motivated and do less effort while adjusting their aspirations [31]. Confidence evolves through experiences in student's life and overconfidence is relevant to the good earning expectation of an individual [32]. Change of specialization is relevant with traits like optimism, sense of identity, work drive and career decidedness together with extraversion, openness, emotional stability and conscientiousness (Foster, 2013)

\section{METHODOLOGY}

Design, respondents, locus, sampling design and size

The study employed quantitative-descriptive survey via a researcher-made questionnaire in which copies are distributed to grade 10 students duly invited and involved senior high schools by complete enumeration. In particular, 188 students from five different sections of grade 10 positively responded and answered the given identical survey. The questionnaires are composed of respondent's profile and 10 questions. 
Gathering of Data.The researchers personally distributed the questionnaires to the grade 10 students of the secondary school for immediate assistance to answer concerns and clarification of the given questions and retrieval of the questionnaires. The data were then collected, tallied and tabulated to be treated with Chisquare $\left(\boldsymbol{x}^{\mathbf{2}}\right)$.

\section{PRESENTATION OF DATA, ANALYSIS, AND INTERPRETATION OF DATA}

This chapter provides the gathered data and the researcher's analysis and interpretation of the results of the distributed surveys. The data were presented in a clearly and concisely in tables.

TABLE I: FREQUENCY OF GENDER \& LEVEL OF INFLUENCE

\begin{tabular}{|c|c|c|c|c|c|c|c|c|c|c|}
\hline Gender & NI & $\%$ & FI & $\%$ & MI & $\%$ & SI & $\%$ & Total & $\%$ \\
\hline Female & 18 & 9.57 & 22 & 11.70 & 20 & 10.64 & 22 & 11.70 & 106 & 56.38 \\
\hline Male & 20 & 10.64 & 21 & 11.17 & 21 & 11.17 & 30 & 15.96 & 82 & 43.62 \\
\hline Total & 38 & 20.21 & 43 & 22.87 & 41 & 21.81 & 52 & 27.66 & 188 & 100.00 \\
\hline
\end{tabular}

Table I shows that students are strongly influenced at $27.66 \%$ of the total population of the students. It is followed by $22.87 \%$ in which indicates that the students are fairly influenced. While $21.81 \%$ indicates that only few of the students are moderately influenced and $20.21 \%$ of the students are not influenced.

TABLE II:FREQUENCY OF SOCIO-ECONOMIC STATUS \& LEVEL OF INFLUENCE

\begin{tabular}{|c|c|c|c|c|c|c|c|c|c|c|}
\hline $\begin{array}{l}\text { Socio-economic } \\
\text { Status }\end{array}$ & $\mathrm{NI}$ & $\%$ & FI & $\%$ & MI & $\%$ & SI & $\%$ & Total & $\%$ \\
\hline 5000 and below & 3 & 1.60 & 9 & 4.79 & 15 & 7.98 & 11 & 5.85 & 38 & 20.21 \\
\hline $5,001-15,000$ & 5 & 2.66 & 31 & 16.49 & 16 & 8.51 & 11 & 5.85 & 63 & 33.51 \\
\hline $15,001-25,000$ & 3 & 1.60 & 27 & 14.36 & 14 & 7.45 & 6 & 3.19 & 50 & 26.60 \\
\hline 25,001 and above & 4 & 2.13 & 10 & 5.32 & 13 & $\begin{array}{l}6.91 \\
30.8\end{array}$ & 10 & 5.32 & 37 & 19.68 \\
\hline Total & 15 & 7.99 & 77 & 40.96 & 58 & 5 & 38 & 20.21 & 188 & 100.00 \\
\hline
\end{tabular}

Table II shows that most of the students in terms of socio-economic status fall between 5,001-15, 000. $40.96 \%$ of the students are fairly influenced, $30.85 \%$ are moderately influenced, $20.21 \%$ are strongly influenced and $7.99 \%$ is not influenced.

TABLE III: FREQUENCY OF STUDENTS BY GENDER \& STRAND

\begin{tabular}{lcccccc}
\hline & Male & $\%$ & Female & $\%$ & Total & $\%$ \\
STEM & 14 & 7.45 & 9 & 4.79 & 23 & 17.55 \\
ABM & 15 & 7.98 & 31 & 16.49 & 46 & 24.47 \\
GAS & 31 & 11.17 & 39 & 20.74 & 70 & 31.91 \\
HUMSS & 9 & 4.79 & 12 & 6.38 & 21 & 11.17 \\
I.T & 5 & 2.66 & 0 & 0.00 & 5 & 2.66 \\
Tech. Voc. & 8 & 4.26 & 15 & 7.98 & 23 & 12.23 \\
\hline Total & 82 & 38.31 & 106 & 56.38 & 188 & 100 \\
\hline
\end{tabular}


Legend: Science, Technology, Engineering and Mathematics (STEM); Accountancy Business and Management (ABM); General Academic Strand (GAS); Humanities and Social Sciences (HUMSS); Information and Technology (I.T); Technical Vocational (Tech. Voc.)

Table III shows that most students had chosen General Academic Strand (GAS) as their strand in which it indicates that they are still undecided of what degree they are going to take up in College. As a sort of suggestion, gender is also a factor in choosing a track. This is particularly important because some have suggested that the choice of the track of women and minorities create differential earnings, which perpetuate class differences. Some researchers argue that gender differences in student track choice are the result of socialization in traditional gender roles [33]. Researchers have explained that women tend to choose disciplines like education, nursing and English because of their female gender role orientation.

TABLE IV: INFLUENTIAL FACTORS AND LEVEL OF INFLUENCE

\begin{tabular}{lllllllllll}
\hline Influential Factors & NI & $\%$ & FI & $\%$ & MI & $\%$ & SI & $\%$ & Total & $\%$ \\
Family Influence & 38 & 20.21 & 57 & 30.32 & 52 & 27.66 & 41 & 21.81 & 188 & 100 \\
Peer Influence & 39 & 20.74 & 95 & 50.53 & 38 & 20.21 & 16 & 8.51 & 188 & 100 \\
Financial Condition & 15 & 7.98 & 74 & 39.36 & 46 & 24.47 & 53 & 28.19 & 188 & 100 \\
\hline Employability & 41 & 21.81 & 69 & 36.70 & 46 & 24.47 & 32 & 17.02 & 188 & 100 \\
\hline Total & 33 & 17.69 & 74 & 39.23 & 46 & 24.20 & 36 & 18.88 & 18.88 & 100 \\
\hline \multicolumn{1}{l}{ Legend: Strongly Influenced (SI=4); More Influenced (MI=3); Fairly Influenced (FI=2); Not Influenced } \\
$\quad($ NI=1)
\end{tabular}

Table IV shows that 295 students are fairly influenced by the influential factors namely; family, peer, financial condition and employability. Most number of students is fairly influenced by their peers and their financial condition in which peer influence is $50.53 \%$ of the total population and financial condition is $39.36 \%$ of the total population. Family is one of the most influential factors that impact Filipino students' career decision [8]. Peer factor is the most consideration of students in choosing a track in Senior High School. Since students' first consideration in choosing a course is their peers, researchers had also observed that the stability of the family's financial source which may pertain to the parent's occupation is considered by the students in choosing a track.

TABLE V: SUMMARY OF RESULTS

\begin{tabular}{lccll} 
& \multicolumn{5}{c}{$\mathrm{N}=188$} & \\
\hline Factors & $x^{2}$ & $x^{2}(.05,3)$ & Decision & Interpretation \\
Family & 1.24 & 7.815 & Failed to Reject & Not Significant \\
Socio-Economic & 15.8 & 7.815 & Reject & Significant \\
Peer Influence & 26.41 & 7.815 & Reject & Significant \\
In-demand & 7.45 & 7.815 & Failed to Reject & Not Significant \\
\hline
\end{tabular}

Legend: Strongly Influenced (SI=4); More Influenced (MI=3); Fairly Influenced (FI=2); Not Influenced $(N I=1)$

In the table above, computed $x^{2}(1.24)$ is lesser than critical $x^{2}{ }_{.05,3}(7.815)$, the $\mathrm{H}_{0}$ is failed to reject. There is no strong evidence that family influence student decision-making in choosing a track in senior high school.

While, in terms of socio-economic, computed $x^{2}(15.8)$ is greater than critical $x^{2}{ }_{.05,3}(7.815)$, then the $\mathrm{H}_{0}$ is rejected. The table shows that socio-economic is significant in student's choice in choosing a track in Senior High School. For practicality reasons, parents usually encourage careers that will not cost much money as well as are stable sources of income [8] 
Third, computed $x^{2}(7.45)$ is lesser than critical $x^{2}{ }_{.05,3}(7.815)$, then the $\mathrm{H}_{0}$ is failed to reject. There is no strong evidence that employability influence student's decision-making in choosing a track in Senior High School track. Occupations included in this category include courses related to legal and social work, education work and personnel work. This could be the common response of students since nowadays graduates find it difficult to find a job even if they have already finished well-known courses such as nursing and education courses [8].

Fourth, computed $x^{2}(26.41)$ is greater than critical $x^{2}{ }_{.05,3}(7.815)$, then the $\mathrm{H}_{0}$ is failed to reject. It is significant in the decision-making of the students in their preference of choosing a track. Peers were also rated highly as individuals that senior high students would approach for help with career planning [8].

To sum up, family and employability are failed to reject and they are not significant in influencing the Grade 10 students in choosing a track in senior high school, socio-economic and peer influence are rejected and are significant in influencing the Grade 10 students in choosing a track in Senior High School. Family and employability do not affect the decision of the students in choosing a track for senior high school while socio-economic and peer influence affect the decision of the students.

\section{DISCUSSION}

This study aims to identify the associative influence in a senior high school track preference which is commonly encountered by the Grade 10 students. With respondents 106 are females and 82 are males, students have varied socio-economic status and it has fairly influenced their choice of track in senior high school. Students had the most number in choosing General Academic Strand (GAS) which indicates that they still doubt of what course to take in college since the track is considered to be a neutral track. Family, peers, financial condition and employability had fairly influenced the students in their preference of a senior high school track. There is a significant association between socioeconomic and peer influence and the level of influence of the grade 10 students in track preference. Researchers have noticed that students are affected by their socio-economic status and peers influencing preference which make choosing a senior high school track as one of the biggest challenges of a student in decision-making and inklings, choice of track may have long-lasting implications including on future earnings because there is growing evidence that at least some portion of the connection between choosing a track in senior high school and wages is casual [34]. Integration of career plans in the curriculum can help students in making sound decision in career selection [8]. Unfortunately, although students have expressed interest in career planning and sought support from parents and friends, students have expressed dissatisfaction with the current system of career counselling [35].

Thinking properly and selecting the right track for students will help them to be ready for their future and choosing the right track can help enhance their skills and capabilities in the track they will choose. Teachers should guide and help their students in choosing the right and appropriate track for them and keep their thoughts and arms open for students who intend to approach them in times of doubts and difficulty in decision-making. Career guidance may be given intensively and be implemented in school through the mandate of the school head. Meanwhile, parents should monitor and support their children for they will have a challenging step for their future. They shall be open to discussion with their son or daughter especially in education and the future that entails with it.

\section{References}

[1]. Konon, A. (2016): Career choice under uncertainty, Beiträgezur Jahrestagung des Vereinsfür Socialpolitik 2016: Demographischer Wandel - Session: Occupational Choice and Job Mobility: Empirical Evidence, No. D18-V2, ZBW - Deutsche Zentralbibliothekfür Wirtschaftswissenschaften, Leibniz-Informationszentrum Wirtschaft, Kiel und Hamburg

[2]. Cheema U.A., Farman A. and Qasim A.P. (2017).Determinants leading to change in career preferences among students of medical college. Allama Iqbal Medical College, 11(3):196-201. DOI: 10.29054/APMC/17.420

[3]. Edwards, K. and Quinter, M. ( 2011). Factors influencing students career choices among secondary school students in Kisumu municipality, Kenya. Journal of Emerging Trends in Educational Research and Policy Studies (JETERAPS).2(2), 81-87, 2011.

http://www.jeteraps.scholarlinkresearch.com/articles/Factors\%20Influencing\%20Students\%20Career\%20Cho ices\%20among\%20Secondary\%20School\%20students\%20in\%20Kisumu\%20Municiality,\%20Kenya.pdf 
[4]. Porter, S. R., \& Umbach, P. D. College major choice: An analysis of person-environment fit. Research in Higher Education, 47, 429-449, 2006.doi:10.1007/s11162-005-9002-3

[5]. Steele, G. (2003) A research-based approach to working with undecided students: A case study illustration. NACADA Journal, $23 \quad(1 \quad \& \quad 2), \quad 10-21$, Spring \& Fall 2003 Retrieved from http://www.nacadajournal.org/doi/pdf/10.12930/0271-9517-23.1-2.10?code=naaa-site

[6]. Lewallen, W. C. (1995). Students decided and undecided about career choice: A comparison of college achievement and student involvement. NACADA Journal, 15 (I) Spring. 22-30.

[7]. Bullock-Yowell, E., McConnell, A.E. and Schedin, E.A. (2014). Decided and undecided students: Career self-efficacy, negative thinking, and decision-making difficulties. NACADA Journal, 34(1), 22-34. doi:10.12930/NACADA-13-016

[8]. Pascual, N. (2014) Factors affecting high school students' career preference. International Journal of Sciences: Basic and Applied Research (IJSBAR), 16(1), 1-14. http://www.urs.edu.ph/wpcontent/uploads/2016/06/2261-4881-1-PB.pdf

[9]. Ahmed, K.A. Sharif, N. and Ahmad, N. (2017)Factors influencing students' career choices: Empirical evidence from business students. Journal of Southeast Asian Research, 1-15. IBIMA Publishing DOI: $10.5171 / 2017.718849$.

[10]. McCann , T.V. Clark, E. and Lu, S. (2010). Bachelor of Nursing students career choices: A three-year longitudinal study. Nurse Education Today 30 (2010) 31-36. doi:10.1016/j.nedt.2009.05.014

[11]. Melander, E. R. (2005) Advising as educating: A framework for organizing advising systems. NACADA Journal, 25 (2) Fall 2005. 84-92.

[12]. Eremie, M.D.(2015). Comparative analysis of factors influencing career choices among senior secondary school students in rivers state, Nigeria. Arabian Journal in Business and Management.5(1).DOI: $10.4172 / 2223-58331000109$

[13]. Tziner, A., Loberman, G., Dekel, Z. and Sharoni, G. (2012 ) The influence of the parent-offspring relationship on young people's career preferences, Revista de Psicología del Trabajo y de las Organizaciones, 28( 2), 99-105. http://dx.doi.org/10.5093/tr2012a8

[14]. Sara, S.S.(2010). Effects of learning styles on career preferences of senior secondary school students in jigawa state Nigeria. Edo Journal of Counselling, 3(1), 132-143.

[15]. Dossajee, H., Obonyo, N. and Ahmed. S. M. (2016). Career preferences of final year medical students at a medical school in Kenya-A cross sectional study. BMC Medical Education (2016) 16:5 DOI 10.1186/s12909-016-0528-1

[16]. Querido, S.J., Vergouw, D., Wigersma, L., Batenburg, R.S., Rond, M.E.J. de, Cate, O.T.J.T. (2016). Dynamics of career choice among students in undergraduate medical courses. A BEME systematic review: BEME Guide No. 33. Medical Teacher, 38(1), 18-29. 10.3109/0142159X.2015.1074990

[17]. Emenyeonu, N.B. (1991). Motivations for choice of course and career preferences of Nigerian female students: Implications for the status of media women in a developing nation. Africa Media Review, 5(2), 7183.

[18]. Hameed, N. N., Jaleal, A. A., Yousef, A. Y. and Ahmed, A.D. (2017). Survey study of future specialization preference and the factors affecting the choice of first, second and third year medical students in college of medicine, Baghdad University, 7(1)Ver.V, 103-107. DOI: 10.9790/7388-070105103107

[19]. Kumar, S. ( 2016). Career choice and college students: Parental influence on career choice traditionalism among college students in selected cities in Ethiopia.International Journal of Psychology and Educational Studies, 3(3), 23-30.

[20]. Fatoki, O. (2014). The Determinants of the career choice of international students in South Africa Mediterranean. Journal of Social Sciences, 5(23), 668-673. MCSER Publishing, Rome-Italy Doi:10.5901/mjss.2014.v5n23p668

[21]. AbouZaid, Z.L., Nabil, N. M., Al-Fadil, S.O., Alatmi, A. and Saeed, A.A. (2014). Career choice and its influencing factors: Perception of senior medical students. Journal of Contemporary Medical Education, 2(3), 168-173. .DOI: 10.5455/jcme.20140911043239

[22]. Gour N, Srivastava D, Adhikari P, Shahi A, Sharma MK, Mahajan PC. (2011). Specialty preference among medical students and factors affecting it. Online J Health Allied Sciences. 2011;10(2):12 URL: http://www.ojhas.org/issue38/2011-2-12.htm

[23]. Prince Famous, I. Adebimpe, O. U., Abiola, A. (2002). Sectoral and career preferences of accounting students: Predisposing factors influencing their choices. Review of Business and Finance, 4 (1), 15-25.

[24]. Patel, R., and Patel, M.(2012). A study on perception and attitude of students regarding factors which they consider while making selection of institute in MBA Programme in Gujarat State. International Refereed Research Journal, III(1), 115-121.

[25]. McGraw, K., Popp, J.S., Dixon, B.L. and Newton, D.J. (2012). Factors influencing job choice among agricultural economics professionals. Journal of Agricultural and Applied Economics, 44(2), 251-265.

[26]. Humlum, M.K., Kleinjans, K.J. and Nielsen, H.S. (2007). An economic analysis of identity and career choice.IZA Discussion Paper No. 3120 
[27]. Clement, L. (2016). External and internal barriers to studying can affect student success and retention in a diverse classroom. Journal of Microbiology and Biology Education, 17(3), 351-359. DOI: http://dx.doi.org/10.1128/jmbe.v17i3.1077

[28]. Cleland, J.A., Johnston, P.W., Anthony, M., Kha, N. and Scott, N.W.(2014) A survey of factors influencing career preference in new-entrant and exiting medical students from four UK medical schools. Biomedical Central. BMC Medical Education 2014, 14:151 http://www.biomedcentral.com/1472-6920/14/151

[29]. Keck, K.J. ( 2016). Factors influencing student major selection at a community college. Masters Theses. 2457. http://thekeep.eiu.edu/theses/2457

[30]. Asif, M., Mohsin, S., Bukhari, R. and Ahmad, A. ( 2015). Research trend, career preferences and its effective factors among undergraduate medical students in Jinnah Sindh medical university, Pakistan. Future of Medical Education Journal, $5(3$ ). mums.ac.ir/j-fmej

[31]. Bickerstaff, S., Barragan, M. and Rucks-Ahidiana, Z. (2017). Experiences of earned success: Community college students' shifts in college confidence. International Journal of Teaching and Learning in Higher Education, 29(3), 501-510.

[32]. Schulz J.F. and Thöni, C. (2016) Overconfidence and career choice. PLoS ONE 11(1): e0145126. doi:10.1371/journal.pone.0145126

[33]. Porter, S. R., \&Umbach, P. D. College major choice: An analysis of person-environment fit. Research in Higher Education, 47, 429-449, 2006.doi:10.1007/s11162-005-9002-3

[34]. Avery, C. Gurantz, O. Hurwitz, M. and Smith, J.(2016). Shifting college majors in response to advanced placement exam scores. National Bureau of Economic Research NBER Working Paper No. 22841, 1-57. DOI: $10.3386 / \mathrm{w} 22841$

[35]. Witko, K., Bernes, K.B., Magnusson, K. and Bardick, A.D. (2005 ). Senior high school career planning: What students want. Journal of Educational Enquiry, 6(1), 34-49, Retrieved from http://www.cred.unisa.edu.au/jee/Papers/JEEVol6No1/Witko.pdf 